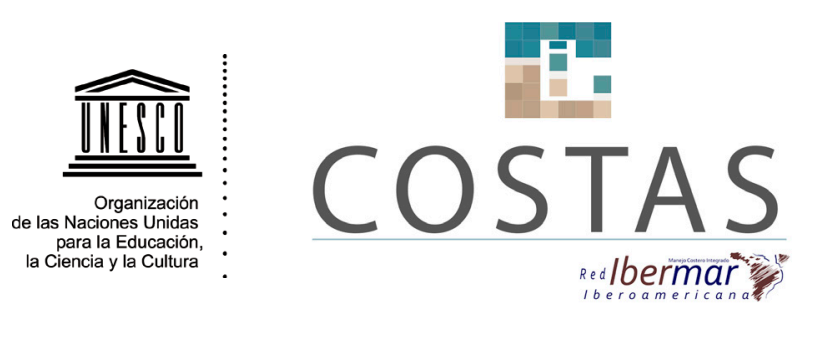

Rivera-Arriaga, E., EI. spejel-Carbajal, F.J. GutiérrezMendieta, L. E. Vidal-Hernández, A. EspinozaTenorio, J.C. Nava-Fuentes, M. García-Chavarría, and A. Sosa-López. 2020. Global Review of ICZM in Mexico. Revista Costas vol esp., 1: 133-154. doi: $10.26359 /$ costas.e107

\title{
Global Review of ICZM in Mexico
}

\author{
E. Rivera-Arriaga ${ }^{1}$, I. Espejel ${ }^{2}$, F. J. Gutiérrez-Mendieta ${ }^{3}$, \\ L. E. Vidal-Hernández ${ }^{4}$, A. Espinoza-Tenorio ${ }^{5}$, J. C. Nava-Fuentes ${ }^{6}$, \\ M. García-Chavarría ${ }^{7}$ and A. Sosa-López ${ }^{1}$ \\ e-mail: evrivera@uacam.mx
}

${ }^{1}$ Instituto EPOMEX,

Universidad Autónoma de Campeche, México.

${ }^{2}$ Facultad Ciencias,

Universidad Autónoma de Baja California, México.

${ }^{3}$ Laboratorio de Ecosistemas Costeros, DCBS,

Universidad Autónoma Metropolitana, Iztapalapa.

México.

${ }^{4}$ Facultad Ciencias, U. Multidisciplinaria de Docencia e Investigación de Sisal, UNAM México.

${ }^{5}$ Departamento Ciencias de la Sustentabilidad, Colegio De la Frontera Sur, Campeche, México.

${ }^{6}$ Consultor Independiente

${ }^{7}$ Instituto EPOMEX, Estudiante de Maestría, Universidad Autónoma de Campeche, México.

Submitted: October 2019

Reviewed: November 2019

Accepted: December 2019

Associate Editor: Marinez Scherer
Keywords: Coastal management, Mexican coastal zone, coastal governance.

\begin{abstract}
In Mexico, the Integrated Coastal Zone Management (ICZM) as it, is an uncommon instrument for coastal management. Nevertheless, ICZM was understood as a regional planning endeavor, similar in perspective to the marine and coastal ecological ordinances performed for all Mexican seas, some coastal municipalities and coastal states, many of which have been published as laws. The exercise of participatory planning has been fully developed in the country, but there is an alarming lack of implementation. In this paper we analyse the top-down policies that rule the marine areas (and coasts). At present the National Policy for the Sustainable Use of Coasts and Seas, is used as the main conveyor for governmental actions and interventions. It was pro-
\end{abstract}




\section{COSTAS}

Revista Costas, No. Esp. 1, 2020

posed by the Inter-ministries Commission for the Sustainable Management of Seas and Coasts (CIMARES) that coordinates the actions of the several dependencies and entities related to the formulation and implementation of national policies for the planning, management and sustainable development of the seas and coasts at the federal level. This is a documental research that analysed the major policies using the methodology of "The Decalogue" which is an analysis of the main aspects of the public administration. The results show that institutional coordination capacity is a major challenge and planning instruments are still miss-used in decision-making processes.

\section{Introduction}

Mexico does not have a long history in developing its coasts and marine resources. It was the beachsun tourism industry that revealed the world's map coastal paradises like Acapulco, Cancun and Los Cabos. Municipalities rule land use and fisheries, oil mining, navigation and marine protected areas are federal controlled. Therefore, most Integrated Coastal Zone Management (ICZM) efforts have been at the national level and designed as regional planning processes and marine ecological ordinances (Espinoza-Tenorio et al., 2014).

The short history of coastal development brought a total population of $14,572,188$ inhabitants within a $100 \mathrm{~km}$ coastal strip in the 2010 census, which is roughly $14.9 \%$ of the total national population (Alvarez-Torres et al., 2015). Notably, the coastal zone displays the highest population growth rate at $2.8 \%$ annually, with further coastal migration expected in the future (Azuz y Rivera-Arriaga, 2007, 2009). Mention should be made to hotspots where 16\% growth rates have been estimated as new tourism cities are developed (Seingier et al., 2009; 2011).

Mexico's marine area is larger than its terrestrial area and comprises approximately 11,600 km of coastline (Figure 1); the territorial sea embraces nearly $291,585 \mathrm{~km}^{2}$ and the Exclusive Economic Zone (EEZ) extends to 3,149,920 km² (Arriaga Cabrera et al., 1998; Burke et al., 2001; Casco, 2004, Contreras and Castañeda, 2004; De la Lanza, 2004). The Mexican Republic consists of 32 states, 17 of which have access to the sea and represent $56 \%$ of the national territory. Within these 17 states, 156 municipalities have beachfront shores and represent approximately $21 \%$ of the continental area of the country (Alvarez-Torres et al., 2015). Escofet (2004, 2009) and Espejel and Bermudez (2009) have produced useful regionalizing maps for marine and coastal ordinances, starting with the five seas that the country recognizes: Gulf of Mexico and Caribbean Sea on the Atlantic Ocean; the California Current Region; the Gulf of California; and the America's Central Pacific Coastal Zone (Rivera-Arriaga and Villalobos (2001) (Figure 1).

As in all coastal countries Mexico is exposed to the threats that Climate Change means (Seinger et al., 2010; Sosa 2010, Pozada y Vega, 2010; González Turrubiates, 2010; Espejel et al., 2010; Andrade, 2019; Arreola et al., 2019; Escamilla-Rivera et al., 2019; Azuz, 2019; Frutos et al., 2019; Seingier et al., 2019; Vegas Castilleja et al., 2019; Fernández y Canul, 2019).

The aim of this paper is to compare and evaluate the major actual federal policies using the methodology named "Decalogue" (Barragan, 2011), which is a qualitative documental analysis of the 10 main aspects of the public administration. 
E. Rivera-Arriaga et al.

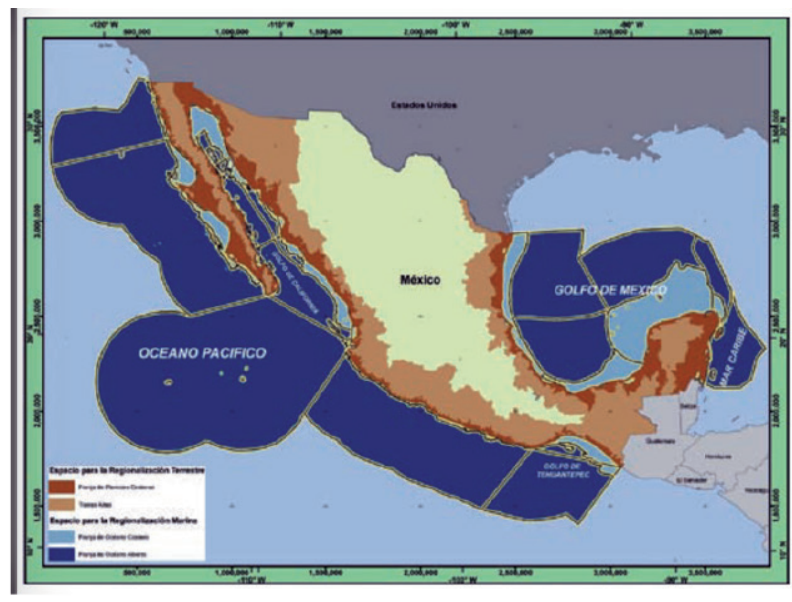

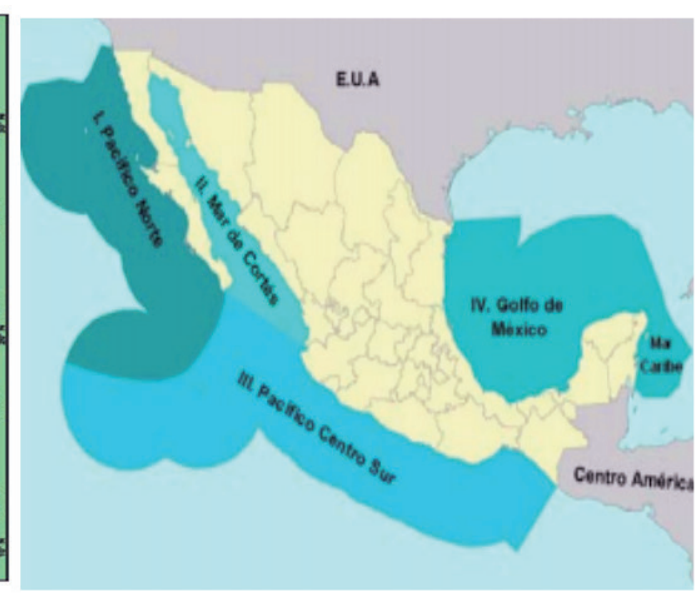

Figure 1. To the left coastal marine regions of Mexico according to Espejel and Bermudez (2009) and to the right the five Mexican seas which are used officially for marine ecological ordinances (source Rivera-Arriaga and Villalobos, 2001).

\section{Methods}

This paper made a top-down qualitative analysis using as framework the qualitative methodology named "Decalogue". The Decalogue methodology (Barragan, 2011, 2012) was proposed by the IBERMAR network which permits to compare and evaluate the situation of the coastal zones through a Decalogue of structural elements of the administrative and legal subsystems: 1) policy; 2) legal framework, 3) institutions; 4) strategies; 5) instruments; 6) managers training; 7) knowledge and research; 8) economical resources; 9) education for sustainability; and 10) public participation.

Additionally, the ten aspects of the "Decalogue" methodology were complemented with the analysis of the 1) institutional capacity, 2) the stakeholder's participation, 3) financial sustainability, 4) the political suitability, and 4) the governance advances that Mexico has achieved pursuing the ICZM.

For this we analysed relevant literature from environmental, economic and social studies published by State government institutions, non-governmental organizations and research institutions. For the analysis we were able to compare the facts from the papers to reality that we collected through questionnaires applied in Garcia (2019), to all the CIMARES institutions that contained three sets of questions that related to efficiency, effectiveness and efficacy. Through their answers we were able to establish relations among literature and institutional answers. Garcia (2019) applying the CONEVAL (2013) methodology, also designed performance indicators to get to know the institutional perception and opinion graded through a Likert scale, regarding their capacity, achievements and advances on the compromises for the Mexican oceans and coasts.

In order to know the institutional performance within the CIMARES, Garcia (2019) made a Strengths, Weakness, Opportunities, Threats (SWOT) analysis for each institutional component. This analysis allowed knowing and assessing the operational conditions of the institutions that conformed CIMARES. Garcia (2019) implemented the methodology developed by Ramirez (2009) that developed the steps for identifying the criteria to anal- 


\section{Fin COSTAS}

yse, as well as the internal and external variables of the SWOT; and also implemented the methodology by Serbolov (2001) who developed a numerical analysis for SWOT, which results in a diagnosis map of the institutional situation.

Two matrixes were developed for internal and external values of SWOT. For both matrix each SWOT component was analysed and each one got a ponderation factor ( $0 \%$ not important; $100 \%$ very important) that was add up vertically to get $100 \%$. Each key factor got a Likert value (1= not important,
$2=$ some importance, $3=$ very important) to assess the response of each institution facing each factor. To get the pondered punctuation each given percentage was multiplied by the Likert value; and finally, all the pondered punctuations were added to each institution for each level of performance (efficiency, effectiveness and efficacy).

To get the strategic performance map, the final results of the matrixes were used to locate in the axis $\mathrm{X}$, $\mathrm{Y}$ the strengths and weakness ( $\mathrm{Y}$, endogenous); and opportunities and threats (X, exogenous) (Figure 2).

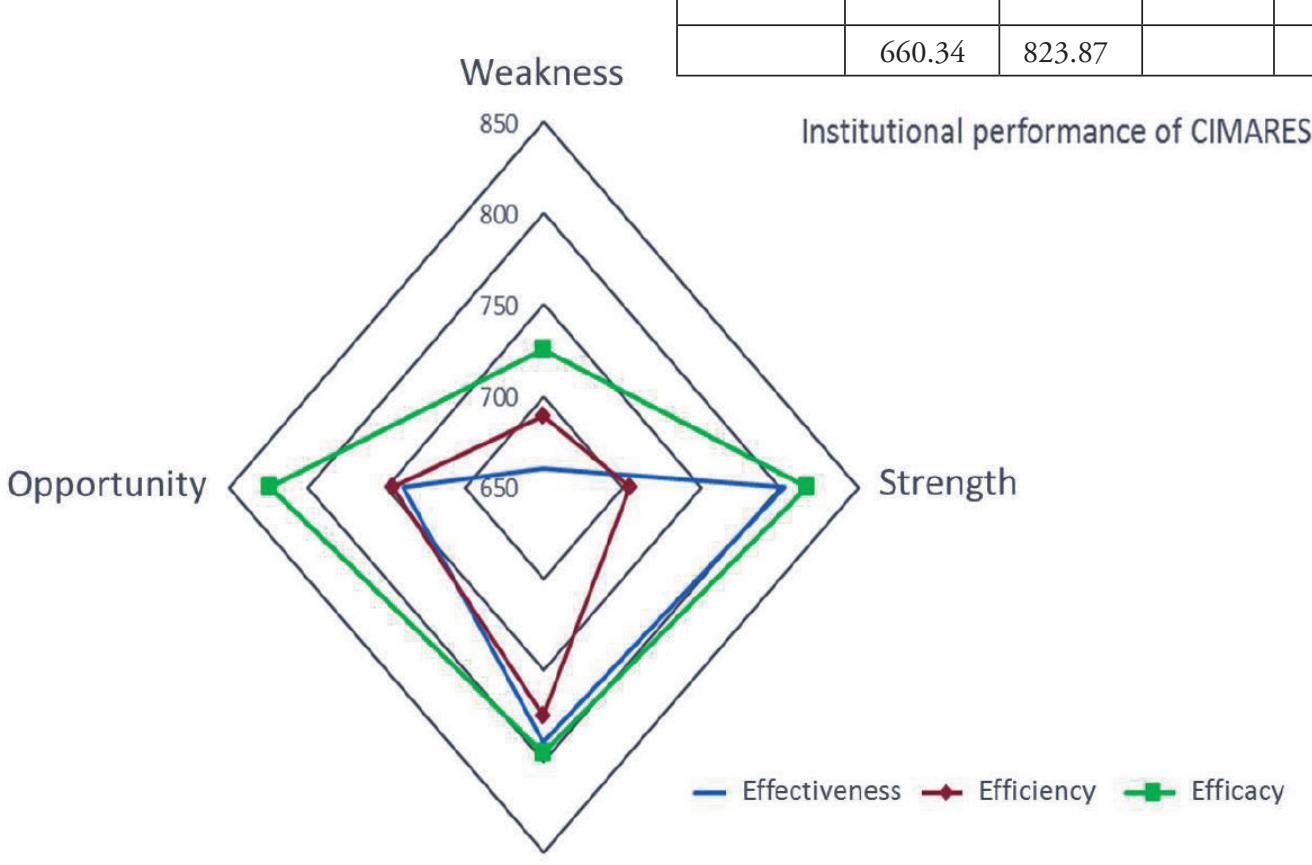

\begin{tabular}{|l|c|c|c|c|}
\hline & Weakness & Strength & Threat & Opportunity \\
\hline Effectiveness & 660.34 & 802.7 & 789.96 & 739.38 \\
\hline Efficiency & 689.12 & 704.89 & 775.54 & 745.6 \\
\hline Efficacy & 725.17 & 817.14 & 795.4 & 823.87 \\
\hline & & & & \\
\hline & 660.34 & 823.87 & & \\
\hline
\end{tabular}

Threat

Figure 2. Institutional performance of CIMARES through the indicators of efficiency, effectiveness and efficacy (García-Chavarría, 2019). 


\section{Results and discussion}

\section{Legal framework for ICZM in Mexico}

Currently, the primary laws governing Mexico's coastal zones include: the Federal Oceans Law of 1986, which pertains to Mexico's national boundaries and Exclusive Economic Zone (EEZ) in accordance with international law; the National Law enshrined in the Mexican Constitution of 1917, which governs land use rights across the nation; the Marine Ordinances, Ecological Ordinances and Urban Development Programs of coastal cities become land-use laws, and the Federal Coastal Zone of 156 municipalities, which governs all federal coastal land zones (Paisley et al., 2003). The Secretariat of the Environment and Natural Resources (SEMARNAT) is the federal office mostly responsible for administration and management of coastal zones. In 2000, its President's Office led the Agenda Del Mar initiative, which "aimed to create a discussion forum for all of the perspectives and activities promoted among the public federal administration and other sectors with a stake in ocean and coastal activities" (Alvarez-Torres et al., 2015).

The legal framework considers only the federal level, leaving the state and municipal governments with minimal possibilities for administrative and participation in decision-making for the coastal and marine zones. Federal efforts for governing the coastal-marine zone are poor facing the variability of the coastal zone local contexts and dynamics. Decisions made from central government lack of enforcement and purpose. Dialogues with Agenda del Mar never took place and left the coastal zone up to this day with a limited vision for a granting permits program through the General Direction of the Federal Marine Zone.

\section{National Policy of Seas and Coasts (PNDSOC)}

Integrated Coastal Zone Management in Mexico took significant steps forward in 2006 with the publication of PNDSOC (National Environmental Policy for the Sustainable Development of Oceans and Coasts: Strategies for its Conservation and Sustainable Use), an integrated policy for the environmental sector with regard to oceans and coasts which was reviewed and amended and finally institutionalized in 2018. The policy ensures that each federal agency has the responsibility to communicate and collaborate with each other and through the different national levels (Federal, State and Municipal) to fulfil its duties, since a lack of coordination between federal agencies has plagued initiatives in the past (Alvarez-Torres et al., 2015). Additionally, PNDSOC was designed to develop integrated management strategies for Mexico's coastal zones, strengthen the coordination between federal, state, and local governments and private institutions, and improve the economic, social, and ecological welfare of coastal regions.

The PNDSOC has three general objectives that seeks the improvement of coastal inhabitants' life conditions though the sustainable development; strengthen local economies and improving the regional ones; incentivizing economic and productive activities liable to coastal-marine environments; and ensure that the structure and functions of coastal-marine ecosystems do not suffer irreversible alterations. Its guidelines recognize the social importance and highlight the relevance of coastal services for coastal populations; the protection and preservation of coastal environments, urges the creation of a $\mathrm{Na}$ tional Coastal Inventory and Ecological Land-use Programs: marine, regional and local with an ICZM scope. 


\section{Fin COSTAS}

Besides the PNDSOC specific policy, other broader or sectorial policies were passed. In 2004, the "Hydric National Policy" was passed with an integrated hydric resource and watershed management. In 2010, the "Wetland National Policy" was published, drafted by the "National Wetlands Committee", where its goals and scope for wetlands sustainable use and protection were based on the RAMSAR Convention Strategic Plan 2009 - 2015 (SEMARNAT, 2010). The main contribution toward the national environmental policy is the inclusion of all coastal environments, including those that have been modified or altered (Nava-Fuentes et al., 2017).

The PNDSOC requires an institutional implementation considering the local governments. Unfortunately, there is limited capacity within the current government for coordinating efforts that include the three levels of government and coastal stakeholders. The coastal and marine policy is supposed to be implemented by a number of governmental institutions, but is currently under the Commission for the Sustainable Management of Seas and Coasts (CIMARES), which is a coordination arrangement among several ministries of the federal government with no teeth nor real power over the coasts and marine zones.

\section{Institutional capacity: Commission for the Sustainable Management of Seas and Coasts CIMARES}

The Inter-ministries Commission for the Sustainable Management of Seas and Coasts (CIMARES by its Spanish acronym) began its functions in June-132008. It is a permanent body whose purpose is to coordinate the actions of the dependencies and entities of the Federal Public Administration, related to the formulation and implementation of national policies for the planning, management and sustainable development of the seas and coasts of the national territory. CIMARES is made up of the Secretariats of the Navy (who chairs it); Governorate; External relationships; Environment and Natural Resources; Energy; Economy; Agriculture and Rural Development; Communications and Transportation; Agrarian, Territorial and Urban Development; and Tourism. CIMARES coordinates and promotes actions that promotes economic opportunities and competitiveness and faces the effects of climate change protecting the goods and services of the nation (https://digaohm.semar. gob.mx/CIMARES.html). It publishes the Seas and Coasts Policy until 30/11/2018.

At national level, CIMARES is entitled is entitled to coordinate management efforts in coastal and marine zones. The ministry in charge of CIMARES is the Ministry of the Navy which acts together with fourteen other ministries to address the main coastal and marine issues through three general objectives and four working groups. The general objectives are the following: 1) Improve life conditions of coastal populations through natural resources sustainable use; integrated land planning and reducing climate change vulnerability; considering a more equitable wealth allocation; 2) Strengthen local economies, improve regional competitiveness, and promoting incentives for coastal and marine economic activities; and 3) Prevent irreversible damages on coastal and marine ecosystems' structures and functions, and promoting their resilience maintaining, inducing, or incrementing their goods and services. The four working groups attending these objectives are the following: 1) Ecological processes land planning; 2) Economy and competitiveness; 3) International Agenda; 4) Ocean Health.

An institutional assessment of the CIMARES was performed during 2018 (Garcia- Chavarría, 2019). Institutional capacity's evaluation is a necessary step for following-up and compliance with the goals and strategies of CIMARES and it was based on indicators of effectiveness, efficiency, and efficacy (ILPES/ CEPAL, 2010). "Effectiveness of public policies 


\section{re \\ COSTAS}

can be defined as the extent to which policies are achieving the benefits they are supposed to achieve plus any unanticipated side benefits. Efficiency of public policies can be defined mainly as the extent to which their benefits and costs are spread among those affected in such a way that no group or individual receive less than a minimum benefit level or a maximum cost level" (Nagel, 1986).

In order to know the institutional capacity of CIMARES, a cross-cutting and within sectorial analysis was performed according to an effectiveness, efficiency, and efficacy methodological approach (Garcia, 2019; CONEVAL, 2013).

The investigation results suggested that there is an absence of coordination, evaluation and monitoring of the various regulatory and planning instruments established to address the effects of climate change and sustainable development objectives 13 and 14 (SDO 13 and SDO14) on oceans and coasts in Mexico. The results also allowed to detect an inconsistent financial support for programs addressed for oceans and coasts related to climate change and sustainability; as well as a poor coordination between ministries involved with CIMARES regarding non-compliance of national nor international climate change and sustainability commitments. It is determined that effectiveness and efficiency analysis suggested that threats that the institutions face for not getting enough funding for implementing the CIMARES' agenda are greater than opportunities; and strengths due to the objectives of CIMARES are greater than weaknesses. There are strengths and greater opportunities; however, the difference between the percentage that we obtained $v s$. weaknesses and threats was low. When the analysis of the degree of performance of the institutions was carried out, low levels of effectiveness and efficiency were observed (Figure 2).

\section{Stakeholder's participation: Roles of national and State actors}

ICZM was understood in Mexico through spatial plans called "Territorial Ordinances", applied to coastal municipalities, marine regions, states, watersheds, and influenced the environmental issues of coastal cities. The basic purpose of these regulations was to enhance local development as Ramirez et al. (2015) mentioned it was "a tool for planning and local development, seen as pillar for the construction of the proposed participation of stakeholders in the public, private and social sector, so that their visions combine the perspective of sustainable management natural resources in the same effort to decide local affairs". According to Espinoza-Tenorio et al. (2014; 386 p) "the Marine Spatial Planning (MSP) has been adopted in Mexico as an environmental planning instrument attending coastal-sea issues and guiding the activities carried out on those realms".

Nevertheless, these regulations were published without complementary economic instruments and other tools to apply the guidelines, so most ordinances still assist authorities to deny conflicting uses, but are useless where illegal or highly economic activities prevail. As well, Espinoza-Tenorio et al. (2014) mention that "its application is still a challenge for the government, who has requested scientists to actively participate in developing proposals in order to promote effective implementation of the MSP trough operative plans: Marine Spatial Planning Programs (MSPP)". The role given to the academia, NGO's and consultancies keep the legal instrument as an experiment to control coastal land-use. One of many lessons learned from applying territorial land-use instruments in large areas and very complex systems is that coastal participative regulations need to be co-generated and promote future co-management of smaller, less heterogeneous and targeted aims such as Arroyo, et al. (2019) propose for alternative protected areas. 


\section{COSTAS}

ICZM can be implemented at different levels in Mexico. Considering that the coastal zone is under the federal government jurisdiction, at national level ICZM is directly in charge of the Ministry of the Environment together with the inter-ministries commission for oceans and coasts CIMARES, in charge of the Navy. At regional level, CIMARES, as a focal point, may implement ICZM strategies also at the Gulf of Mexico region; the Mexican Caribbean region; etc. At local level, ICZM may be implemented for any municipality's coastal zone or even at a smaller scale, at any city's water-front. The federation has a signed agreement with each coastal municipality granting it the ICZM responsibilities. And each coastal municipality has an environmental or development department in charge of the ICZM. It is important to clarify that this department most of the time does not enable any ICZM activity or plan. The shared benefits from the fees collected in the Federal Coastal Zones are used in each coastal municipality in a discretionary form.

There are three possible structures for implementing ICZM in Mexico. Considering the federal leadership, there is a top-bottom implementation that requires that CIMARES works with four different topics (1. land ordinances processes; 2. economy and competitiveness; 3. international agenda; 4. ocean health) through working groups conformed by individuals from different participant ministries. Each group meet and develop an agenda under the same common objectives that had been previously identified by CIMARES:

- General Objective 1. To contribute to improve life conditions for coastal communities through the sustainable use of natural resources, implementing ICZM and reducing vulnerability to climate change while promoting an equitable shared benefit

- General Objective 2. To strengthen local economies; improving regional competitiveness; con- tributing to national economy; and to encourage economic and productive responsible activities to coastal and marine environments.

- General Objective 3. To ensure that coastal and marine ecosystems structure and function do not suffer irreversible damages; improve their resilience, and keep and increment their ecological goods and services and their landscape value.

This top-bottom implementation occurred at national or regional levels. Another implementing structure is bottom-up lead by the municipality which organize an advisory group that would tackle the identified coastal issue. This advisory group may integrate "Regidores" and "Síndicos" (advisers and vigilantes of the municipal interests); local deputies; issue-related municipal departments; issue-related state and federal ministries; academia; private sector; and organized civil society. And a third implementing structure for ICZM may involve the leadership of an organized civil society or the academia helping a coastal community in the bottom-up ICZM process. In this case an advisory group is conformed, and coastal issues are identified through a participatory process together with government authorities.

In Mexico there is no division of authority over ocean issues among other levels of government but the federal one. The Mexican Constitution established this, and therefore, oceans and coastal zones that correspond to 20 meters in width by the National Assets Law, are part of the national goods. Moreover, local government actions should be consistent with the national development policies and legal framework. Any discrepancies or issues would be settled through agreements and coordination agendas. At local level, the federation may grant individuals permits for the use of parts of the coastal zone for a certain period of time. These permits may be issued to the state or municipal governments as well. Nevertheless, coastal issues may be produced by the poor capacity of the municipal and state governments in 
addressing their responsibilities. For example, coastal waters bad quality may result from the absence of municipal water treatment; as well as littering that may have occurred from the lack of and adequate solid waste management. Despite the division of authority over ocean issues among national and subnational levels of government, federal authorities are willing to aid the municipal and state governments through financial and technical aid.

Ocean and coastal issues may arise on federal-local linkages with hydrocarbon exploitation and fisheries in the Bank of Campeche in the Gulf of Mexico. Fisheries activities are banned from oil and gas extraction facilities, reducing the possibilities of fishers for their activities at coastal municipalities. This issue imposes a few conflicts on the municipality, but mainly on the national oil company PEMEX and the federal energy and fisheries authorities. After de Energy Reform (2013-2014) further economic and political challenges emerged because of a new institutional framework and actors in the governance arena such as international oil companies (e.g., Exxon, ENI, CHEVRON). These unprecedented circumstances have stressed the historically fragile equilibrium between fisheries and oil industry in the Gulf of Mexico (Rivera-Arriaga et al., 2019).

The Ministry of Environment and Natural Resources (SEMARNAT) has primary responsibility for creating a federal ICZM policy, although many other federal agencies have similar and even overlapping responsibilities with regards to the coastal region as seen in Table 1. SEMARNAT led the project to prepare PNDSOC, which aimed to establish an inter- and intra-institutional coordination mechanism for efficiently addressing current and emerging management and planning issues in the ocean and coastal zones (Alvarez-Torres et al., 2015). Ultimately, Agenda del Mar (the federal initiative guiding PNDSOC) "transitioned to a decentralized model, granting state governments partial, but limited, stewardship over the coastal zone" in large part by enhancing coordination at the operational level (Alvarez-Torres et al., 2015).

The federal government of Mexico is not the sole party responsible for coastal management policy. Coordination among federal, state, and local government entities has come a long way in the past few decades as many individual communities take the initiative in managing their own coastlines with the help of federal resources. In 2015, Alvarez-Torres et al. described the poor communication before PNDSOC as a result of "different visions and competences in the coastal region and the country as a whole," claiming the lack of coordination "increased when the different sectors could not reach a consensus on productive activities and conservation strategies, thereby risking the sustainability of efforts made in each region." However, some observers still view the coordination framework as insufficient and short sighted, with more action needed on creating solid, long term integration strategies (Azuz et al., 2018).

\section{Financial sustainability of the coastal zone}

The revenue generated by state and local levels is by the concession and payments for the right of use and exploitation of the ZOFEMAT (Maritime and Terrestrial Federal Zone). Even though this revenue must be designated for the management, maintenance and preservation of this zone; in a period analysed by Nava-Fuentes et al. (2017) it was not a specific designation and a clear correlation in revenue uses, given that $20.6 \%$ of ZOFEMAT is franchised $(2292.74 \mathrm{~km}$ of the $11,122 \mathrm{~km})$.

A prime example of an innovative financing solution is the Temporary Employment Program (PET), a cash-for-work social safety net program created to assist in economic recovery from natural disasters, and other crisis alleviation programs, especially those affecting the fisheries industry. Over time, the PET has become a major support mechanism for coastal 


\section{監 \\ COSTAS}

Table 1. Stakeholders in the integrated ocean and coastal strategy in Mexico. (Alvarez- Torres et al., 2015).

\begin{tabular}{|c|c|}
\hline Institution & \\
\hline \multirow{18}{*}{ Federal } & $\begin{array}{l}\text { Ministry of Agriculture, Livestock, Rural Development, Fisheries and Food } \\
\text { (Secretaría de Agricultura, Ganadería, Desarrollo Rural, Pesca y Alimentación, SAGARPA) }\end{array}$ \\
\hline & National Fisheries Commission (Comisión Nacional de Acuacultura y Pesca CONAPESCA) \\
\hline & National Fisheries Institute (Instituto Nacional de la Pesca, INP) \\
\hline & Ministry of Tourism (Secretaría de Turismo, SECTUR) \\
\hline & National Trust Fund for Tourism Development (Fondo Nacional de Fomento al Turismo, FONATUR) \\
\hline & Ministry of the Navy (Secretaría de Marina, SEMAR) \\
\hline & Ministry of Communications and Transport (Secretaría de Comunicaciones y Transportes (SCT) \\
\hline & Ministry of Economy (Secretaría de Economía, SE) \\
\hline & Ministry of Social Development (Secretaría de Desarrollo Social, SEDESOL) \\
\hline & Ministry of Energy (Secretaría de Energía, SENER) \\
\hline & Mexican State Oil Corporation (Petróleos Mexicanos, PEMEX) \\
\hline & Federal Electricity Commission (Comisión Federal de Electricidad, CFE) \\
\hline & $\begin{array}{l}\text { Ministry of Environment and Natural Resources (Secretaría de Medio Ambiente y Recursos Naturales, } \\
\text { SEMARNAT) }\end{array}$ \\
\hline & $\begin{array}{l}\text { National Commission for Natural Protected Areas (Comisión Nacional de Áreas Naturales Protegidas, } \\
\text { CONANP) }\end{array}$ \\
\hline & National Water Commission (Comisión Nacional del Agua, CONAGUA) \\
\hline & National Forestry Commission (Comisión Nacional Forestal, CONAFOR) \\
\hline & $\begin{array}{l}\text { National Ecology and Climate Change Institute (Instituto Nacional de Ecología y Cambio Climático, } \\
\text { INECC) }\end{array}$ \\
\hline & National Congress \\
\hline \multirow[t]{3}{*}{ Local } & State governments \\
\hline & Municipal governments \\
\hline & Local Congress \\
\hline \multirow[t]{2}{*}{ Social } & Non-governmental organizations (NGOs) \\
\hline & Coastal communities \\
\hline Academia & Universities and research institutions \\
\hline Private & Industry and Commerce \\
\hline
\end{tabular}

regions, directing funds towards mangrove and wetlands hydrological systems restoration, marine mammal and turtle protection, and beach, river, cenotes, and wetlands clean-up actions (Alvarez-Torres et al., 2015). Additionally, the program has been applied to enhancing coastal resilience in the face of climate change, while some states and municipalities have been able to build and train their own environmental and Land-Sea Use Plan departments. The program has also enhanced legal frameworks and led to the development of air quality networks and vehicle verification processes (Alvarez-Torres et al., 2015). 


\section{ris \\ COSTAS}

\section{Education for sustainability: Capacity development and raising awareness.}

The Sectoral and Regional Integration division within the Directorate General for Environmental Policy has emphasized Land-Sea Use Plans (LSUP) as a central component to sustainable management with the goals of green development and climate change adaptation (Alvarez-Torres et al., 2015). LSUPs have evolved to become a key tool for local governments in addressing risk and vulnerability issues (Alvarez-Torres et al., 2015). As a binding instrument, having a published LSUP allows coastal communities to access resources necessary to prevent and alleviate coastal disasters. LSUPs often involve all three levels of government, as well as academia, NGOs, organized social groups, stakeholders, and the private sector, in order to "provide general environmental, social, economic assessment of the threats that each marine zone faces" (Alvarez-Torres et al., 2015).

The National Council of Environmental Education for Sustainability is the responsible entity of making recommendations to the SEMARNAT for the formulation and evaluation of strategies, policies, programs and projects on environmental education; as well as linking with other consultative bodies or public participation spaces and collaboration with the Center for Education and Training for Sustainable Development (CECADESU).

In 2006, the "Environmental Education Strategy for Sustainability in Mexico" was passed with the aim to enhance the government participation in environmental aspects, with educational institutions under the framework of the "Decade of the United Nations Education for Sustainable Development (20052014)" which resulted in an increase of environmental education within formal basic education (SEP, 2013). Nevertheless, continuity into higher educational levels is lacking; as well as the development of strategies to avoid generational gaps. Likewise, uni- versities, municipalities, aquariums and NGOs have developed initiatives to highlight the importance of oceans preservation; however, in most of the cases, due to the lack of resources, they were isolated and without continuity (Nava-Fuentes et al., 2017).

Four mechanisms of public participation within SEMARNAT were identified, which aimed to involve society in the decision making for the environmental protection and natural resources management and sustainable use. Nevertheless, public participation had been considered as a mere procedure, which in some cases was limited to the projects, programs and plans published in the institutional website. The lack of disclosure makes inquiries go unnoticed by the society who is practically not involved. Besides, coastal populations are characterized by a low economical income with poor accessibility to both new technologies and internet so this kind of public consultation is not really efficient or adequate.

On the other hand, there were a growing number of NGOs and organized groups interested in preserving coastal resources, which have been a key component to raise awareness and have served as agents for stopping projects that were approved by the federal government but with a high negative impact in the coastal environment.

Moreover, there is an important diversity of governmental expertise among the natural coastal and marine resources, derived from more than one hundred years of history of controlling the extractive use of fish, invertebrates, mangrove woods, sediments and coastal waters. However, as a consequence of such fragmented view of systems components and fluxes for administrative reasons, those capacities have been exceeded, thus it is still necessary to create academic and integral administrative capacities for better research and decision-making teams. Members of these trained teams will need to incorporate multidisciplinary experience, information, theories and methodologies, will be able to construct a con- 


\section{昰 COSTAS}

textualized vision of the coastal-marine issues, will conceptualize constant change as the basic element of the coasts and, will incorporate concepts of complex systems, adaptive management and theory of change as mentioned by Arora et al. (2019); and as a consequence they will offer possible explanations and more integrated solutions. This base for integrated coastal management can only be efficiently implemented when human capital is formed explicitly in this field of knowledge.

In Mexico there are 63 public universities (7 federal, 34 states and 22 states with solidarity support) and various research centres that serve $52 \%$ of undergraduate students and $48 \%$ of graduate students (ANUIES, 2018). Among the 17 coastal states of the country, 11 have at least one university education program related to scientific and technical knowledge and coastal management; These programs are better represented within Mexican Pacific states (e.g. Baja California, Baja California Sur, Jalisco, Sinaloa, Colima, Chiapas and Oaxaca) than in Atlantic states (Quintana Roo, Yucatán, Campeche and Veracruz). At the undergraduate level there are ten educational programs whose graduation profile or special lines of specialization include the study of areas of knowledge that can support proposals for production, conservation and protection of coastal resources. Among them, there are five programs of Marine Biology, four of zones or coastal resources management, and one of systems engineering, taught in the following universities: University of Guadalajara (CUCSUR), Autonomous University of Yucatan (UADY); University of the Sea of Oaxaca (UMAR); Veracruzana University (UV), Autonomous University of Baja California Sur (UABCS), University of Chiapas (UNACH), Autonomous University of Sinaloa (UAS), University of Colima (UCOL), University of Quintana Roo (UQROO) and National Autonomous University of Mexico (UNAM, Yucatan Campus).
Revista Costas, No. Esp. 1, 2020

In graduate programs, Mexico has a specialization in Environmental Management from the Autonomous University of Baja California, six master's degrees and seven doctorates in Sciences, Marine-Coastal Sciences or Marine Ecology and a specific multidisciplinary Master's degree for the management of the coastal zone. Again, these programs are taught mainly in $\mathrm{Pa}-$ cific states (e.g. Baja California, Baja California Sur, Sinaloa, Jalisco and Oaxaca) and only two in Atlantic States (e.g. Quintana Roo and Campeche). In half of these programs, emphasis is placed on learning and developing research capacities in: Marine biology. Marine Geology, Marine Ecology and Systematics, Oceanography, Marine Chemistry and Population Dynamics; and in productive activities such as commercial fisheries, aquaculture and tourism; while the other half includes research on aspects of natural resource management, coastal and insular management, sustainable management and the application of geographic information systems, in order to prevent and propose possible solutions to problems related to the conservation and exploitation of natural coasts resources.

In addition, there are other graduate programs in general sciences taught by research centres and colleges in Mexico that prepare students for the study and management of coastal resources through research and participation in technical-scientific consultancies; for example: the Centre for Research and Higher Studies of Ensenada (CICESE, Master's and Doctorate in Earth Sciences or Life Sciences), the College of the Northern Frontier (Colef, Master of Integrated Environmental Management), the Autonomous University of Baja California (Master in Management of Ecosystems of Arid Zones and Doctorate of Environment and Development), Centre for Research and Advanced Studies of the IPN Mérida Unit (CINVESTAV, PhD in Sciences with a specialty in Marine Sciences), El Colegio de la Frontera Sur in 
Campeche, Chetumal, San Cristobal de Las Casas, Tapachula and Villahermosa headquarters (ECOSUR, Master of Science in Natural Resources and Rural Development, Doctorate in Sciences in Ecology and Sustainable Development), etc. (Table 2).
As documented by Vidal and colleagues (2019), these interdisciplinary study programs are aimed at contributing to the integrated management of coastal zones in Mexico with a humanist perspective that analyses the daily socio-environmental problems of

\begin{tabular}{|c|c|c|}
\hline \multirow[t]{2}{*}{ Level of studies } & \multicolumn{2}{|c|}{ Study Programs } \\
\hline & Atlantic & Pacific \\
\hline \multirow{4}{*}{ Undergraduate } & Natural Resource Management, UQROO & Engineer in coastal systems, UNACH \\
\hline & $\begin{array}{l}\text { Sustainable Management of Coastal Zones, } \\
\text { UNAM Yucatán }\end{array}$ & Management of Coastal Zones, UAS \\
\hline & Marine Biology UADY, UV & $\begin{array}{l}\text { Marine Biology, CUCSUR, UMAR, } \\
\text { UABC }\end{array}$ \\
\hline & Hydrobiology, UAM-I & $\begin{array}{l}\text { Management of Marine and Port Resourc- } \\
\text { es, UCOL }\end{array}$ \\
\hline Specialty & & Environmental Management, UABC \\
\hline \multirow{4}{*}{ Graduate (Masters and Doctorate) } & Marine Sciences and Limnology, UNAM & Marine and Coastal Sciences, UABC \\
\hline & $\begin{array}{l}\text { Sciences with specialty in Marine Sciences, } \\
\text { CINVESTAV, Yucatán }\end{array}$ & Coastal Oceanography, UABC \\
\hline & & Earth Sciences, CICESE \\
\hline & & Life Sciences, CISESE \\
\hline \multirow{4}{*}{ Masters } & $\begin{array}{l}\text { Multidisciplinary Masters for the manage- } \\
\text { ment of the coastal-marine zone, UAC }\end{array}$ & Sciences: Marine Ecology, UMAR, UABC \\
\hline & $\begin{array}{l}\text { Sciences in Natural Resources and Rural } \\
\text { Development, ECOSUR }\end{array}$ & Sciences in Aquatic Resources, UAS \\
\hline & & $\begin{array}{l}\text { Comprehensive Environmental Manage- } \\
\text { ment, COLEF }\end{array}$ \\
\hline & & Management of Arid Zones, UABC \\
\hline \multirow{4}{*}{ Doctorate } & $\begin{array}{l}\text { Sciences in Ecology and Sustainable Devel- } \\
\text { opment, ECOSUR }\end{array}$ & Sustainable Development, UQROO \\
\hline & & $\begin{array}{l}\text { Sciences in Biosystematics, Ecology and } \\
\text { Management of Natural and Agricultural } \\
\text { Resources, CUCSUR }\end{array}$ \\
\hline & & Marine Ecology, UMAR \\
\hline & & Environment and Development, UABC \\
\hline
\end{tabular}




\section{Fi: COSTAS}

these areas. With this goal, students must understand and deal with transversal tensions that arise from addressing issues such as democratic culture, multiculturalism, sustainable development, education for good living and environmental education, human rights and environmental justice, total value of nature, risk , among others; and be challenged to: analyse, discuss, integrate, innovate in the methodologies of analysis, take positions, work in interdisciplinary teams and learn a process of constant change that requires rehearsing and learning from error. However, integrated management learning experiences of the coastal zone in Mexico are isolated, and cases of learning with the coastal management of a resource are much more common (e.g. a beach, a kind of fish); sectorial coastal management (e.g. ports); management to serve a couple of interconnected sectors (e.g. ports and tourism); management of a coastal area (e.g. coastal lagoon, reef system), that fully integrates geographic, thematic, intergovernmental, temporal, strategic and intersectorial experiences. It is also clear that our teaching experiences tend to focus on the analysis of the impacts of one activity from one coastal area to another, on the needs of sectorial development and, more rarely, on the study of coastal risks; but always with the constant of having deficient databases and the lack of political and administrative coordination to make management decisions with a holistic and long-term vision.

Some formal training aspects still need to be developed in the education of ICZM in the country; these include documented evaluation of how different types of curriculum (e.g. formal, real, hidden and null) incorporate attributes that define ICZM and how teaching models adapt to facilitate the construction of skills and competencies necessary for graduates "to learn while doing". Some optimal teaching strategies to be dominated are: horizontal discussion in the classrooms; access to experiences outside the classroom as an academic object of study; highlight the importance of context and teaching by projects. It is also necessary to promote the link between institutions, companies and organizations and diverse members of society related to the professional work of a coastal area manager for the provision of diverse services and professional practices that contribute to the enrichment of said institutions, programs and students. In other words, these links will contribute to carry out and update the profile of Professional Practice, and the relationship of the study plans with the social need.

Mexico faces and will face several challenges in the creation of professional capacities to plan and mitigate the growing demand for environmental resources and services from the coasts, and with this, the opportunity to innovate in the teaching strategies and linking mechanisms of the study programs arise.

\subsection{Governance and ICZM}

Governance addresses the values, policies, laws, and institutions by which a set of issues are addressed; it probes the fundamental goals and the institutional processes and structures that are the basis for planning and decision making (Olsen et al., 2009). A thorough understanding of critical institutional, legal, and policy drivers at international, national and local scales is key to ensuring the relevance and effectiveness of an ICZM strategy.

Governance in coastal areas is challenging in Mexico. Positive achievements are the marine ordinances, and such is the case of the Gulf of California, Gulf of Mexico and the Caribbean Sea, South and North Pacific. The real consequences have not yet been evaluated, but these ordinances have made the mobility and integration of actors from the academy, government, and communities possible.

Scholars are strongly implicated in several government initiatives, especially those related to environ- 


\section{Fis COSTAS}

mental management (Cordova et al., 2006). Several institutions whose investigators have kept close contact with government agencies as advisors and participants in several coordination committees at regional and local levels (Fraga et al., 2009).

The Non-Governmental Organizations (NGOs) have played a vital role in the transition to new forms of coastal governance in Mexico. NGOs' work was mostly focused on environmental issues such as endangered species (e.g. flamingos, vaquita marina, and sea turtles), habitat protection, and natural protected areas. However, over the last couple of decades, NGOs have shifted their objectives and now are playing a crucial role in working with users for the sustainable management of fisheries and ecosystems (Espinosa-Romero et al., 2014). Currently, NGOs' work includes efforts to promote increased scientific information and the use of traditional knowledge, supporting the development of management plans, building local capacities, promoting information sharing across different levels, and fortifying fishers' organization and participatory processes (Herman 2004; Basurto et al., 2000).

However, many things should change in Mexico to be able to build an efficient and effective governance process. There is a high degree of difficulty to close the gap between the goals and objectives of environmental and sectorial policies conceived by the federal government and its translation into actions and specific management achievements at other levels of government (Fraga et al., 2009).

For Mexico's coastal management, it is necessary to take into account the fact that many ministries are involved, due to the vast marine zones and the vital role they play in the national economy, especially concerning to oil, tourism, and fishing. These economic activities require a substantial state control due to its importance in the national economy, in a situation that minimizes local authorities.

\section{The ICZM analysis through the Decalogue}

Quesada et al. (2018) notes that Mexico currently faces obstacles in implementing ICZM practices, namely the lack of adequate legal and policy frameworks for ICZM and the struggle to enforce existing ICM laws and policies (Table 3). It is therefore essential that Mexico places a stronger political emphasis on implementing a robust policy and legal framework for ICZM, in addition to maintaining strong enforcement measures.

\section{Particular issues facing ICZM in Mexico}

There is a high complexity that characterizes the relationships between highly diversified groups of users and institutions. Many difficulties related to governance are frequently associated with a false or blurred distinction between territories and the limits of the social groups that exploit them; Federal government changes occurring in Mexico every six-year, administrative modifications are registered having consequences in coastal management.

Due to the recent and tumultuous development of the Mexican academic research system, much of the knowledge accumulated centres on commercial resources, and the renovation of the system itself is geographically inconsistent.

CONACYT continues supporting sectorial research aimed at diagnosis and technical management of species economically important or protected, but it does not promote an academic discussion of the research priorities nor the possibilities according to the national capabilities.

This situation results in a complex and fluctuating administrative system, where short and contrasting contextual conditions cause a kind of tug-of-war in Mexican marine policy- making (Espinoza-Tenorio et al., 2010). In such a way, that in order to respond to the international agencies, several ministries have established, through committees of citizens participation, public consult mechanisms in order to rein- 
Table 3. Decalogue of the SPA's in ICZM in Mexico.

\begin{tabular}{|c|c|}
\hline Aspect & General diagnosis \\
\hline Policy & $\begin{array}{l}\text { Until the presentation of PNDSOC in 2006, ICZM was not a priority on the political agenda; neverthe- } \\
\text { less in } 2018 \text { the National Policy for the Sustainable Use of Coasts and Seas was passed. } \\
\text { Additionally, there is a National Wetland Policy and the National Policy. }\end{array}$ \\
\hline Legal framework & $\begin{array}{l}\text { There is no specific law for coastal zones regulation; laws are still sectorial. The demarcation is established } \\
\text { by the General Law of National Assets with the ZOFEMAT figure which is considered as arbitrary and } \\
\text { did not consider natural ecosystem's boundaries. There is a gap between "land" and "sea" regulations. In } \\
2018 \text {, an initiative of the "Coastal Law" was presented but dismissed. }\end{array}$ \\
\hline Institutions & $\begin{array}{l}\text { In Mexico the management of coastal zones relies in institutions of the three administrative levels, which } \\
\text { means that, in the State and Municipal scale, depends on the administration of each local government. } \\
\text { In the federal scale the SEMARNAT is responsible for monitoring and managing the Mexican coast. } \\
\text { However there are other institutions with intervention on specific resources. The importance of this area } \\
\text { was highlighted through the creation of the CONANP in } 2000 .\end{array}$ \\
\hline Strategies & $\begin{array}{l}\text { Prior to the approval of the National Policy, coastal strategies depended on administration priorities, } \\
\text { without an interest in integrated coastal management. The interest in developing oceanic and coastal } \\
\text { spatial plans initiated together with a strategy on Climate Change (2007) and Wetlands (2013). }\end{array}$ \\
\hline Instruments & $\begin{array}{l}\text { The main instruments related to ICZM are the Regional and Maritime Ecological Spatial Plans which } \\
\text { are present in three of the four regions (North Pacific, Gulf of California; Gulf of Mexico and Carib- } \\
\text { bean Sea). Additionally, } 54 \text { protected areas located on the coast were approved. Fisheries Management } \\
\text { Plans for } 18 \text { species with commercial interest. Spatial planning of coastal municipalities and "Municipal } \\
\text { Climate Action Plans". Existing operational tools are the Environmental Impact Assessments, Mexican } \\
\text { Official Standards, fishing quotas and concessions of the ZOFEMAT. }\end{array}$ \\
\hline Managers training & $\begin{array}{l}\text { There are currently } 25 \text { higher education programs with an ICZM approach. Nevertheless, administrative } \\
\text { vacancies are still demanding managers with a sectorial profile dismissing the importance of the ICZM } \\
\text { approach. }\end{array}$ \\
\hline $\begin{array}{l}\text { Knowledge and } \\
\text { research }\end{array}$ & $\begin{array}{l}\text { The importance of coastal and marine ecosystems has increased through government institutions (IN- } \\
\text { ECC and CONABIO), research centres and universities; however, knowledge of the current status of } \\
\text { certain ecosystems and their distribution is still limited. A geographic information system that integrates } \\
\text { the status and distribution of coastal ecosystems is missing. }\end{array}$ \\
\hline $\begin{array}{l}\text { Economical } \\
\text { resources }\end{array}$ & $\begin{array}{l}\text { An increase in public spending on projects focusing on coastal areas was registered. However, they were } \\
\text { focused on building infrastructure, contrasting with the increase of resources designated to Climate } \\
\text { Change programs. }\end{array}$ \\
\hline $\begin{array}{l}\text { Education for sus- } \\
\text { tainability }\end{array}$ & $\begin{array}{l}\text { Education for sustainability is a duty of SEMARNAT, which should formulate and develop environmen- } \\
\text { tal education strategies. In 2006, the "Environmental Education Strategy for Sustainability in Mexico" } \\
\text { was created despite not including a coastal-marine approach. NGOs are important actors in the develop- } \\
\text { ment of education programs; however, they are concentrated only in certain regions of the country. }\end{array}$ \\
\hline Public participation & $\begin{array}{l}\text { Community participation is considered as a mere process to be performed. Social group's representatives } \\
\text { that focus on the preservation of coastal ecosystems are not adequately represented. }\end{array}$ \\
\hline
\end{tabular}


force their initiatives; however, the number of those, and their lack of coordination, without mentioning that their composition and responsibilities may vary from one ministry to the other (Fraga et al., 2009). The current situation is largely dysfunctional with

\section{Conclusions}

Coastal and maritime areas are of high importance for Mexico due to their total extension, abundant natural resources, human settlements and diverse economic and social activities. However these areas also face a number of anthropic and natural threats that challenge national and local capabilities to reach sustainable development objectives as enunciated at international compromises, mainly those referring to climate actions and its effects (SDO13) and life below water (SDO14).

Most government capabilities to improve coastal inhabitants' life conditions, strengthen local economies and ensure structural and functional ecosystems permanence have been addressed by political statements, definition of institutional competencies and planning instruments, mainly territorial and marine ordinances that provide guidelines for a sustainable use of the coastal and marine zones. Although some local implementation and coordination experiences have succeeded, at national level there are critical government strategies that need to be improved. $\mathrm{Ma}$ jor challenges appear when inter and intra institutional agency coordination is required, since sectorial perspectives strongly persist in decision making and local government capabilities are differentially constructed by unequal decentralization processes. Up to now, planning instruments are still misused for decision-making.

Economic mechanisms to generate funds to efficiently manage coastal zones by concessions and permits of coastal resources are still in development regard to the challenges of sustainable marine management. A complicated mixture between unbeaten management and academic vestiges caused the present circumstances of an enhanced but limited governance system.

stages. Currently there are deficient data bases of areas under legal or illegal use and proper labelling of generated income is not insured for environmental and development purposes. Other economic mechanisms to promote voluntary responses for the benefit of the preservation of coastal natural resources and the sustainable development of their communities need to be explored.

Education and awareness raising programs have influenced some social participation of Mexican academia, NGOs, organized social groups, stakeholders and private sectors for coastal resource management and sustainable use; but there is still a long path to go to. It is required that participation could be expressed in active involvement in the decision process with co-responsibility to implement control and surveillance measures that could replace the passive reception of information on environmental challenges in the coastal areas.

Particularly outstanding is the contribution of public universities and research centres throughout the country to train future coastal managers in general sciences with strong management capacities; however, the increase of real experiences within institutions, companies, organizations and diverse society members will contribute to carry out and update this professional profile. Mexico's capacity for ICZM is based on a legal structure but requires it to be strengthened at its financial and operational capacity.

Finally, integrated perspective of coastal management is needed in the country. Ecosystem Based 


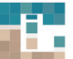 COSTAS}

Management of mangrove wetlands, coral reefs, sea grasses, and dune-beach systems among other natural coastal ecosystems, is required to decrease their vulnerability and increase the resilience to climate

\section{References}

Arora, A., , E., Gogoi, D., Joy, P., Kumar, R., Luthra, U., Pal, A., Pervaiz, Rumbaitis del Rio, C. 2019. Bringing adaptive management to life: Insights from practice. Learning paper Action on Climate Today, Oxford Policy Management. https://reliefweb.int/sites/reliefweb.int/files/resources/ACT-Adaptative-management- Proof3-1.pdf

Alvarez-Torres, P., Díaz-de-León-Corral, A., Perez-Chirinos, G., Aguilar, J. C., Rosado, R., Burgoa, F. E., Cortina, S., Ibáńez, M., Brachet, G., Sevilla, N.P.M., Rivera-Arriaga, E., Adeath, I. A. 2015. Development of a National Ocean Policy in Mexico. In: Routledge Handbook on National and Regional Ocean Policies. Abingdon, Oxon: Routledge. p. 294- 310.

Andrade, M. (forthcoming 2020). El riesgo, la vulnerabilidad y la protección civil por efectos en la variabilidad del clima. In: Rivera-Arriaga E., Azuz- Adeath, I, Espinoza, A., Ortega-Rubio, A., Silva Casarín, R., Vázquez Botello A., Vega Serratos, E., Cervantes, O. (eds.) Gobernanza y Manejo de las costas y mares ante la incertidumbre. Una guía para tomadores de decisiones. Red Temática RICOMAR CONACYT, Instituto EPOMEX-UAC.

ANUIES. 2018. Visión y acción 2030 Propuesta de la ANUIES para renovar la educación superior en México Diseńo y concertación de políticas públicas para impulsar el cambio institucional. ANUIES México D.F. $181 \mathrm{p}$.

Arreola Lizárraga, J.A., García Morales, G., León López, C.E., y Ortega Rubio, A., (forthcoming 2020). Playas recreativas de México: vulnerabilidad y gestión. In: Rivera-Arriaga E., Azuz- Adeath, I, Espinoza, A., Ortega-Rubio, A., Silva Casarín, R., Vázquez Botello A., Vega Serratos, E., Cervantes, O. (eds.) Gobernanza y Manejo de las costas y mares ante la incertidumbre. Una guía para tomadores de decisiones. Red Temática RICOMAR CONACYT, Instituto EPOMEX-UAC. Arroyo, M., Levine, A., \& Espejel, I. 2019. A transdisci-
Revista Costas, No. Esp. 1, 2020

change effects. ICZM would supply governance with the required framework to face changes in the coastal and marine zones related to old and new challenges.

plinary framework proposal for surf break conservation and management: Bahía de Todos Santos World Surfing Reserve. Ocean \& Coastal Management, 168: 197-211.

Azuz Adeath, I., \& Rivera Arriaga, E. 2007. Estimación del crecimiento poblacional para los estados costeros de México. Papeles de población, 13(51): 187-211.

Azuz-Adeath, I., \& Rivera-Arriaga, E. 2009. Descripción de la dinámica poblacional en la zona costera mexicana durante el periodo 2000-2005. Papeles de población, 15(62): 75-107.

Azuz, I., Le Bail, M., Munoz, N., Cortes Ruiz, A. 2018. Coastal Development: Construction of a Public Policy for the Shores and Seas of Mexico. 10.1016/B9780-12- 810473-6.00003-0.

Azuz, I., (forthcoming 2020). La variabilidad climática en las zonas costeras. In: Rivera-Arriaga E., AzuzAdeath, I, Espinoza, A., Ortega-Rubio, A., Silva Casarín, R., Vázquez Botello A., Vega Serratos, E., Cervantes, O. (eds.) Gobernanza y Manejo de las costas y mares ante la incertidumbre. Una guía para tomadores de decisiones. Red Temática RICOMAR CONACYT, Instituto EPOMEX-UAC.

Barragán Muñoz, J.M. (coord.). 2011. Manejo Costero Integrado y Política Pública en Iberoamérica: Propuestas para la acción. Red IBERMAR (CYTED), Cádiz, 280 pp.

Barragán, J.M. (coord.). 2012. Manejo Costero Integrado en Iberoamerica: Diagnostico y propuestas para una nueva política pública. Red IBERMAR (CYTED), España, p. 152.

Basurto X, Bourillon L., Torre J. 2000. The role of a Non-Governmental Organization (NGO) in an emerging co-management regime: the Mexican Seri Indians' case study. In: Proceedings of the 8th Biennial conference of the International Association for Study of Common Property (IASCP); 2000. 26 p. 
Caetano, E. Marton, L. Innocentini, V. Domínguez, C. Caracas A. Galván, L. 2017. El cambio del nivel del mar y eventos externos en el Pacífico mexicano. p. 85-104. In: Botello, A.V., Vilanueva, S., Gutiérrez, J., Rojas Galavíz, J.L. (eds.) Vulnerabilidad costera de las zonas costeras de Latinoamérica al cambio climático. UJAT, UNAM, UAC, 476 p.

Cicin-Sain, B., VanderZwaag, D. L., Balgos, M. C. 2015. Routledge Handbook of National and Regional Ocean Policies. Abingdon, Oxon: Routledge. Retrieved from http://search.ebscohost.com/login. aspx?direct $=$ true $\& \mathrm{db}=$ nlebk\&AN $=1086838 \&$ site $=\mathrm{e}-$ host- live

Córdova y Vázquez, A., Rosete-Verges, F., Enríquez-Hernández, G., Hernández-de- laTorre, B., 2006. Ordenamiento Ecológico Marino. Visión temática de la regionalización. SEMARNAT, INE, DF, México.

CONEVAL, 2013. Guía para la Elaboración de la Matriz de Indicadores para Resultados. México DF, https:// www.coneval.org.mx/Informes/Coordinacion/Publicaciones\%20oficiales/GUIA_PARA_LA_ELABORACION_DE_MATRIZ_DE_INDICADORES. pdf

Escofet, A. 2004. Aproximación conceptual y operativa para el análisis de la zona costera de México: un enfoque sistémico-paisajístico de multiescala. Facultad de Ciencias Marinas Instituto de Investigaciones Oceanológicas, UABC, Ensenada.

Escofet, A. 2004. Marco operativo de macro y mesoescala para estudios de planeación de zona costera en el Pacífico mexicano. Rivera-Arriaga E, Azuz I, Villalobos G. El manejo costero en México. México: Centro EPOMEX, Universidad Autónoma de Campeche, 223-233.

Escofet en Córdova, A., Rosete, F., Enríquez, G., \& Hernández, B. (2009). Ordenamiento ecológico marino visión integrada de la regionalización. INE, México, DF.

Escamilla-Rivera, V., Castro-Campos, U. y Villalobos, G., (forthcoming 2020). Análisis de vulnerabilidad y gestión de riesgo por inundación en áreas de cuencas. In: Rivera-Arriaga E., Azuz- Adeath, I, Espinoza, A., Ortega-Rubio, A., Silva Casarín, R., Vázquez Botello A., Vega Serratos, E., Cervantes, O. (eds.) Gobernanza y Manejo de las costas y mares ante la incertidumbre. Una guía para tomadores de decisiones. Red Temática
RICOMAR CONACYT, Instituto EPOMEX-UAC.

Espejel, I., \& Bermúdez, R. 2009. Propuesta metodológica para la regionalización de los mares Méxicanos. Ordenamiento Ecológico Marino: visión integrada de la regionalización. SEMARNAT, INE, México, 151-224.

Espejel; I., Palacios-Chávez, V., León, C., Nieves, C., García Gastélum, A., 2010. El imperativo de la incorporación del riesgo en la planeación y gestión de nuevas ciudades, un ejercicio analítico para un puerto por nacer, Cap. 39: 545-560. In: Rivera-Arriaga E., Azuz Adeath, I, Alpuche Gual, L., y Villalobos, G. (eds.), Cambio climático en México: un enfoque costero y marino, 940 p.

Espinosa-Romero, M.J., Rodríguez, L.F., Weaver, A.H., Villanueva-Aznar, C., Torre, J. 2014. The changing role of NGOs in Mexican small-scale fisheries: From environmental conservation to multi-scale governance. Mar. Policy, 50: 290-299. https://doi. org/10.1016/j.marpol.2014.07.005

Espinoza-Tenorio, A., Moreno-Báez, M., Pech, D., Villalobos-Zapata, G. J., Vidal- Hernández, L., Ramos-Miranda, J., Mendoza-Carranza, M., Zepeda-Domínguez, J. A., Alcalá-Moya G., Pérez-Jiménez, J. C., Rosete, F., León, C., Espejel, I. 2014. El ordenamiento ecológico marino en México: un reto y una invitación al quehacer científico. Latin American Journal of Aquatic Research, 42(3): 386-400.

Fernández, V., y Canul, R., (forthcoming 2020). Evaluación de inundación costera debido al incremento del nivel del mar en Ensenada Baja California, México. In: Rivera-Arriaga E., Azuz- Adeath, I, Espinoza, A., Ortega-Rubio, A., Silva Casarín, R., Vázquez Botello A., Vega Serratos, E., Cervantes, O. (eds.) Gobernanza y Manejo de las costas y mares ante la incertidumbre. Una guía para tomadores de decisiones. Red Temática RICOMAR CONACYT, Instituto EPOMEX-UAC.

Fraga, J., Villalobos, G.J., Doyon, S., García, A. 2009. Descentralización y manejo ambiental Gobernanza Costera en México, Descentralización y Manejo Ambiental.

Frutos, M., Solano, E., Cuevas, E., Escobar, I.G., (forthcoming 2020). Vulnerabilidad y riesgo socioambiental en localidades del área natural protegida de T'ñerminos, Campeche, México. In: Rivera-Arriaga E., Azuz- Adeath, I, Espinoza, A., Ortega-Rubio, A., Silva Casarín, R., Vázquez Botello A., Vega Serratos, 


\section{酯 \\ COSTAS}

E., Cervantes, O. (eds.) Gobernanza y Manejo de las costas y mares ante la incertidumbre. Una guía para tomadores de decisiones. Red Temática RICOMAR CONACYT, Instituto EPOMEX-UAC.

García Chavarría, M. 2019. Determinación de la Capacidad de México para cumplir con los compromisos internacionales de cambio climático en materia de océanos y costas. Tesis de Maestría, Fac. Ciencias Químico-Biológicas, Instituto EPOMEX, Universidad Autónoma de Campeche. P. 200.

González-Martínez, G., Bellido-Castaños, M. E. 2017. Desarrollo de la noción de curriculum. p. 21-34. In: Bellido-Castaños M.E (Coord.) Planeación y evaluación curricular. UNAM. FES Zaragoza, México D.F

González-Turrubiates, D.M., 2010. Valoración y gestión del riesgo por inundaciones en municipios costeros (una aproximación con base en indicadores), Cap. 36: 591-606. In: Rivera-Arriaga E., Azuz Adeath, I, Alpuche Gual , L., y Villalobos, G. (eds.), Cambio climático en México: un enfoque costero y marino, 940 p.

Herman, H. 2004. El papel de las organizaciones de la sociedad civil en el manejo costero en México, p. 115132. In: Rivera-Arriaga, E., Villalobos-Zapata, G., Azuz-Adeath I., and Rosado-May, F., (eds.) El manejo costero en México, p. 654

INECC, 2018. Programa especial de cambio climático 2014-2018. (https://www.gob.mx/inecc/acciones-y-programas/efectos-del-cambio-climatico).

Jennerjahn, T.C., Gilman, E., Krauss, K.W., Lacerda, L.D., Nordhaus, I., Wolanski, E. 2017. Mangrove Ecosystems under Climate Change. In: Rivera-Monroy, V., Lee, S., Kristensen, E., Twilley, R. (eds) Mangrove Ecosystems: A Global Biogeographic Perspective. Springer, Cham. https://doi.org/10.1007/978-3319-62206-4_7

Lithgow, D., Martínez, M. L., Gallego-Fernández, J. B., Silva, R., Ramírez-Vargas, D. L. 2019. Exploring the co-occurrence between coastal squeeze and coastal tourism in a changing climate and its consequences. Tourism Management, 74: 43-54.

López-Medellín, X., Ezcurra, E., González-Abraham, C., Hak, J., Santiago L. S., Sickman, J.O. 2011. Oceanographic anomalies and sea-level rise drive mangroves inland in the Pacific coast of Mexico. Journal of Vegetation Science, 22: 143-151

Magaña, V., Gómez, L., Neri, C., Landa, R., León, C., Ávila, B. 2011. Medidas de adaptación al cambio
Revista Costas, No. Esp. 1, 2020

climático en humedales del Golfo de México.DF, México: INE SEMARNAT UNAM BM UAM.

Martínez, M. L., Mendoza-González, G. Silva-Casarín, R., Mendoza-Baldwin, E. 2014. Land use changes and sea level rise may induce a "coastal squeeze" on the coasts of Veracruz, Mexico. Global Environmental Change, 29: 180-188.

Mata-Zatas, E.J., Gama, L., Vázques-Navarrete, C., DíazLópez, H., Figueroa-Maheng J.M. Rincón-Ramírez, J. 2017. Vulnerabilodad de los servicios ecosistémicos en la zona de inlfuencia de la Reserva de Los Pantanos de Centla, ante la elevación de nivel medio del mar asociada al cambio climático. p. 193-230. In: Botello, A.V., Vilanueva, S., Gutiérrez, J., y Rojas Galavíz, J.L. (eds.) Vulnerabilidad costera de las zonas costeras de Latinoamérica al cambio climático. UJAT, UNAM, UAC, $476 \mathrm{p}$.

McLeod, K., Leslie, H., 2009. Ecosystem-Based Management for the Oceans. Island Press, Washington DC, p. 368 .

Nava-Fuentes, J. C., Granados, P. A., Martins, F. C. 2017. Coastal management in Mexico: Improvements after the marine and coastal policy publication. Ocean \& Coastal Management, 137: 131-143. doi:10.1016/j. ocecoaman.2016.12.017.

Nagel, S.S., 1986. Efficiency, effectiveness and equity in public policy evaluation, Policy Studies Review, vol. 6 (1) https://doi.org/10.1111/j.1541-1338.1986. tb00651.x

Nordstrom, K. F. 2000. Beaches and dunes on developed coasts. Cambridge, UK: Cambridge University Press, p. 347.

Olsen, S.B., Page, G.G., Ochoa, E. 2009. The Analysis of Governance Responses to Ecosystem Change: A Handbook for Assembling a Baseline. LOICZ reports \& Studies No. 34. GKSS Research Centre. Geesthacht.

Ortiz Pérez, M.A., 2016. La zona costera: estructura, dinámica, amenazas y conflictos futuros. In: Moncada Maya, López López, J.O. (eds.), Geografía de México. Una reflexión espacial contemporánea. Universidad Nacional Autónoma de México, CDMX, México, pp. 71-85.

Ortiz Pérez, M.A., de la Lanza Espino, G. 2006. Diferenciación del espacio costero de México. Serie Textos Universitarios 3. UNAM. Instituto de Ingeniería. $138 \mathrm{p}$. 
Osland, M. J., Fehera, L. C., López-Portillo, J., Day, R. H., Suman, D., Guzmán Menéndez, J. M., Rivera-Monroy, V. H. 2018. Mangrove forests in a rapidly changing world: Global change impacts and conservation opportunities along the Gulf of Mexico coast. Estuarine, Coastal and Shelf Science, 214:120-140.

Pedrozo-Acuña, A., Damania, R., Laverde-Barajas, M. A., Mira-Salama, D. 2015. Assessing the consequences of sea-level rise in the coastal zone of Quintana Roo, México: the costs of inaction. Journal of Coastal Conservation 19: 227-240; DOI 10.1007/s11852015-0383-y

Posada Venegas, G., y Vega Serratos, B.E., 2010. Evaluación de zonas inundables para la ciudad de San Francisco de Campeche, Cap. 37: 607-622. In: Rivera-Arriaga E., Azuz Adeath, I, Alpuche Gual , L., y Villalobos, G. (eds.), Cambio climático en México: un enfoque costero y marino, $940 \mathrm{p}$.

Quesada, G., Klenke T., C., Mejía-Ortíz, L. M. 2018. Regulatory Challenges in Realizing Integrated Coastal Management-Lessons from Germany, Costa Rica, Mexico and South Africa. Sustainability, 10(10): 3772. doi:10.3390/su10103772

Ramírez, J. 2009. Procedimiento para la elaboración de un análisis FODA como una herramienta de planeación estratégica en las empresas. Ciencia Administrativa No. 2: 55-61. Instituto de Investigaciones y Estudios Superiores de las Ciencias Administrativas, Univ. Veracruzana, México. http://www.uv.mx/iiesca/ fi les/2012/12/herramienta2009-2. pdf

Ramírez, A. G., Cruz, A., Morales, C. N., Monterroso, R. I. 2015. El ordenamiento ecológico territorial instrumento de política ambiental para la planeación del desarrollo local. Estudios sociales, 26(48): 71-99.

Rivera-Arriaga, E. y G. Villalobos (2001). The coast of Mexico: approaches for its management. Ocean \& Coastal Management, 44: 729-756.

Rivera-Arriaga, E., O. López-Chan, L.A. Williams-Beck, R. León Olea and A. Gutiérrez-Rivera. 2019. Hydrocarbon governance in the gulf of Mexico: Building a benefit-sharing system, Ocean and Coastal Management, 177: 156-165

Ruiz-Ramírez, J.D., Euán-Ávila, J. I., Rivera-Monroy, V. H. 2019. Vulnerability of Coastal Resort Cities to Mean Sea Level Rise in the Mexican Caribbean. Coastal Management, 47(1): 23-43, DOI: 10.1080/08920753.2019.1525260
Saunders, M.I, Leon, J. X., Callaghan, D. P., Roelfsema, C. M., Hamylton, S., Brown, C. J., Baldock, T., Golshani, A., Phinn, S. R., Lovelock, C. E., Hoegh-Guldberg, O., Woodroffe, C. D., Mumby, P. J. 2014. Interdependency of tropical marine ecosystems in response to climate change. doi: 10.1038/ nclimate 2274

SEMARNAT. 2010. Política Nacional de Humedales. Comite Nacional de Humedales. Secretaría de Medio Ambiente y Recursos Naturales, Mexico, p. 253.

SEMARNAT. 2018. DOF 28/04/2014 Programa Especial de Cambio Climático 2014-2018. https://plataformacelac.org/politica/261

Seingier, G., Espejel, I., \& Fermán-Almada, J. L. (2009). Cobertura vegetal y marginación en la costa mexicana. Investigación Ambiental, 1(1): 54-69.

Seinger, G., Espejel, I., Ferman J.L., Delgado, O., 2010. Vulnerabilidad de las poblaciones costeras ante la peligrosidad natural, enfoque estatal y municipal, Cap. 41: 669-688. In: Rivera-Arriaga E., Azuz Adeath, I, Alpuche Gual, L., y Villalobos, G. (eds.), Cambio climático en México: un enfoque costero y marino, $940 \mathrm{p}$.

Seingier, G., Espejel, I., Fermán-Almada, J. L., Montaño-Moctezuma, G., Azuz-Adeath, I., \& Aramburo-Vizcarra, G. (2011). Mexico's coasts: Half-way to sustainability. Ocean \& Coastal Management, 54(2): 123-128.

Seingier, G., espejel, I., y Orozco-Jiménez, O., (forthcoming 2020). Gobernanza ambiental ante el cambio climático en municipios costeros de México. In: Rivera-Arriaga E., Azuz- Adeath, I, Espinoza, A., Ortega-Rubio, A., Silva Casarín, R., Vázquez Botello A., Vega Serratos, E., Cervantes, O. (eds.) Gobernanza y Manejo de las costas y mares ante la incertidumbre. Una guía para tomadores de decisiones. Red Temática RICOMAR CONACYT, Instituto EPOMEX-UAC.

SEP. 2013. Educación por niveles. Subsecretaría de educación básica. http://basicaSEP.gob.mx/.

Serbolov, Y. (2001). Los mapas de diagnóstico. La Carpeta Purpura, 342, pp.1-20.

Sierra-Correa, P.C., Cantera Kintz, J. R. 2015. Ecosystem based adaptation for improving coastal planning for sea-level rise: A systematic review for mangrove coasts. Marine Policy, 51: 385-393.

Sosa Ferreira, A.P., 2010. Condiciones socioeconómicas y vulnerabilidad de la península de Yucatán, Cap. 38: 


\section{ris \\ COSTAS}

623-638. In: Rivera-Arriaga E., Azuz Adeath, I, Alpuche Gual , L., y Villalobos, G. (eds.), Cambio climático en México: un enfoque costero y marino, $940 \mathrm{p}$.

The United States and Mexico, Ocean \& Coastal Law Jour. http://digitalcommons.mainelaw.maine.edu/ oclj/vol $9 /$ iss $2 / 4$

Vagas Castilleja R. del C., Rolón Aguilar, J.C., Treviño Trujillo, J., Tobías Jaramillo, R. (forthcoming 2020). Anomalías climáticas futuras en una cuenca hidrológica costera del Golfo de México: Impacto de escenarios de cambio climático. In: Rivera-Arriaga E., Azuz- Adeath, I, Espinoza, A., Ortega-Rubio, A., Silva Casarín, R., Vázquez Botello A., Vega Serratos, E., Cervantes, O. (eds.) Gobernanza y Manejo de las costas y mares ante la incertidumbre. Una guía para tomadores de decisiones. Red Temática RICOMAR CONACYT, Instituto EPOMEX-UAC.
Vidal-Hernández L, Guadarrama, P., Arredondo-García M.C., Espejel, I., Rivera-Arriaga, E., Mascaró, M. (forthcoming 2020). Formación educativa para los gestores en la solución de problemas en las áreas costeras de México. Entre la formación en programas de licenciatura y los programas de posgrado o especialidad. In: Rivera-Arriaga E., Azuz- Adeath, I, Espinoza, A., Ortega-Rubio, A., Silva Casarín, R., Vázquez Botello A., Vega Serratos, E., Cervantes, O. (eds.) Gobernanza y Manejo de las costas y mares ante la incertidumbre. Una guía para tomadores de decisiones. Red Temática RICOMAR CONACYT, Instituto EPOMEX-UAC.

Williams, S. J. 2013. Sea-level rise implications for coastal regions. Journal of Coastal Research SI 63(18): 4-196 